\section{Thyroid orbitopathy possibly predisposes to late-onset of periocular lymphoma}

CM Nutting ${ }^{1}$, S Shah-Desai ${ }^{2}$, GE Rose ${ }^{2}$, AP Norton ${ }^{3}$ and PN Plowman'
Hashimoto's thyroiditis, coeliac disease, or Helicobacter gastritis. Eye (2006) 20, 645-648. doi:10.1038/sj.eye.6702027; published online 26 August 2005

Keywords: Graves' disease; thyroid orbitopathy; periocular lymphoma; autoimmune disease; orbital lymphoma

\section{Introduction}

Chronic inflammation of extra-ocular muscles and periocular fat in thyroid orbitopathy (ophthalmopathy) is due to cell-mediated and humoral immunity, with frequent serum antibodies against thyroglobulin, thyroid microsomes, and thyroid stimulating hormone (TSH) receptors. The strong association of autoimmune thyroid orbitopathy and autoimmune thyrotoxicosis suggests a shared antigen for both conditions - the favoured one being TSH receptors on the preadipocyte sub-population of periocular fibroblasts. ${ }^{1,2}$

Several autoimmune diseases predispose to lymphoma, with a typical latency of 10-20 years - such as Hashimoto's thyroiditis, ${ }^{3-5}$ Sjögren's syndrome, ${ }^{6,7}$ and coeliac disease. ${ }^{8,9}$ Inflammatory glandular destruction and MALT acquisition in Sjögren's syndrome renders such patients about 44 times more likely to develop late-onset marginal zone lymphoma (MZL) in affected tissues. ${ }^{7}$ Lymphocyte accrual during the chronic inflammation of Hashimoto's thyroiditis predisposes to later lymphoma (most commonly follicle centre cell variant ${ }^{4}$ ) and intestinal lymphomas arising with coeliac disease (typically 7 years after onset ${ }^{8}$ ) are predominantly of high-grade T-cell histology. ${ }^{9}$ The chronic inflammation of gastric MALT due to Helicobacter pylori infection, although not autoimmune, also predisposes to the emergence
'Departments of Clinical Oncology, London, UK

${ }^{2}$ Moorfields Eye Hospital, London, UK

${ }^{3}$ Pathology, St Bartholomew's Hospital, London, UK

Correspondence: GE Rose, Orbital Clinic, Moorfields Eye Hospital, City Road, London EC1V 2PD, UK

Tel: + 447566 2034;

Fax: + 440117928

E-mail:geoff.rose@ moorfields.nhs.uk

Published online: 26 August 2005 
of gastric marginal zone lymphoma, ${ }^{10,11}$ and eradication of the infection can lead to disease regression. ${ }^{12}$

We report a series of patients with autoimmune thyrotoxicosis and thyroid orbitopathy, who later developed periocular lymphoma.

\section{Patients and methods}

Database records for patients with biopsy-proven lymphoma of the orbit or lids (hereafter termed 'periocular' lymphoma), treated at the Orbital Clinic at Moorfields Eye Hospital, were reviewed for a history of thyroid gland disease or thyroid orbitopathy. For those patients with a database history of thyrotoxicosis or thyroid orbitopathy, the clinical case notes were reviewed with special regard to the nature and chronology of the various conditions. Ethical review was not required for a retrospective investigation.

\section{Results}

A total of 369 patients were recorded, between 1979 and 1999 , as presenting with periocular lymphoma, and 20 $(5.4 \%)$ had evidence of a thyroid abnormality. Adequate clinical case notes were available for only 10 patients with autoimmune thyroid disease.

Six of the 10 patients had thyroid orbitopathy (Figure 1), four bilateral, with a median age of 36.5 years at diagnosis (range 23-64 years): 3/6 had medical treatment for thyrotoxicosis and $2 / 6$ had systemic

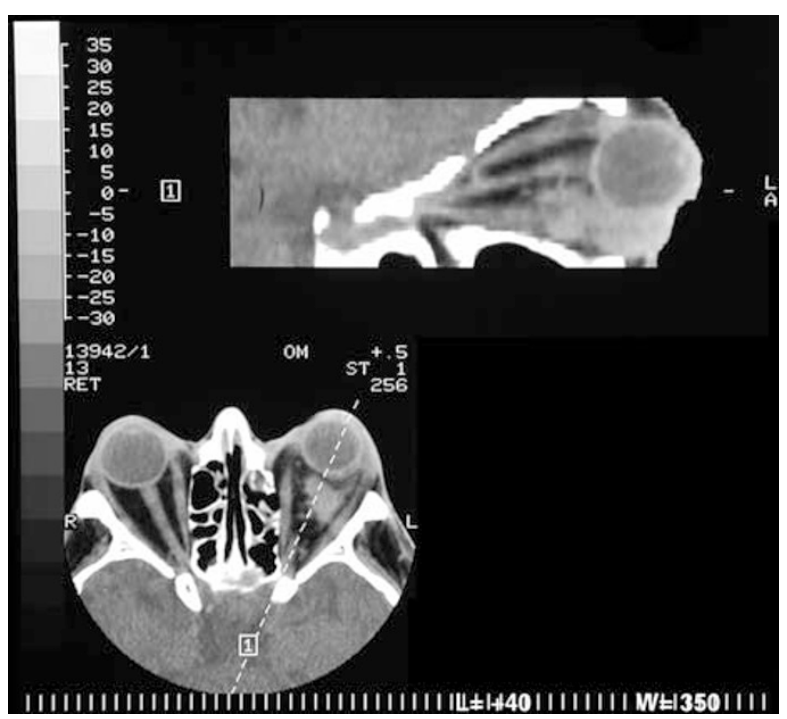

Figure 1 MR images demonstrating biopsy-proven lymphomatous infiltration of the left eyelid and anterior orbit, in the presence of bilateral diffuse extraocular muscle enlargement due to longstanding thyroid ophthalmopathy. steroids and orbital decompression for ophthalmopathy; none underwent orbital radiotherapy or radio-iodine therapy. The median latency between diagnosis of thyroid orbitopathy and development of periocular lymphoma in the six patients was 17.5 years (range 15-27 years). In 4/10 patients without prior ophthalmopathy, the diagnosis of lymphoma and thyrotoxicosis was simultaneous in two patients, but with a latency of 17 and 51 years in the two others (the lymphoma being of later onset in each case).

All lymphomas were solely periocular (unilateral Stage IE) at presentation, being marginal zone variant in 9/10 and diffuse large B-cell lymphoma in one patient; the tumour affected mainly the retrobulbar tissues in three cases, the lacrimal gland (two cases) or the conjunctiva (five patients). The periocular disease was treated with external beam radiotherapy (30-32 Gy, in 2 Gy fractions) and the patient with diffuse large B-cell lymphoma received 3 cycles of $\mathrm{CHOP}$ adjunctive chemotherapy. All patients were alive at more than 5 years after the diagnosis of lymphoma, with a 5-year disease-free survival of $89 \%$ (Table 1 ).

\section{Discussion}

Owing to problems in case-note retrieval after more than two decades (only 10/20 notes being adequate for analysis), it is probable that this investigation's estimate for the prevalence of thyroid orbitopathy or autoimmune thyrotoxicosis after periocular lymphoma is too low. On this basis, among our patients with lymphoma the prevalence estimates for thyroid ophthalmopathy would appear to be at least $6 / 369(1.6 \%)$, and at least $10 / 369$ $(2.7 \%)$ for autoimmune thyroid gland disease.

Although the annual incidence of thyroid ophthalmopathy in Olmsted County, Minnesota, was estimated as 16/100000 for women and 2.9/100000 for men, ${ }^{13}$ such data cannot readily be used for prevalence calculations. A reported UK prevalence of thyrotoxicosis is $2.2 \%,{ }^{14}$ of which nearly two-thirds is autoimmune - that is, $1.4 \%$ prevalence. There have been various and changing reported incidences for overt ophthalmopathy in patients with autoimmune thyroid disease, ${ }^{15}$ but a recent UK estimate is about $30 \%{ }^{16}$ - giving a UK population estimated prevalence of about $0.4 \%$ (30\% of $1.4 \%$ ); at this prevalence, there should have been no more than two cases of orbitopathy among our 369 lymphoma patients. The observed prevalence of at least $6 / 369(1.63 \%)$ patients with thyroid ophthalmopathy in our series is, therefore, highly unlikely to have occurred by chance $(P=0.007)$.

Primary periocular lymphomas are uncommon, about $85 \%$ are low-grade (such as marginal zone, diffuse lymphoplasmacytoid, or follicle cell lymphoma ${ }^{17}$ ), and 
Table 1 Patients with periocular lymphoma who had prior autoimmune thyroid gland disease

\begin{tabular}{|c|c|c|c|c|c|c|c|c|c|c|}
\hline \multirow[t]{2}{*}{ Patient sex } & \multicolumn{3}{|c|}{ Details of prior thyroid orbitopathy } & \multirow{2}{*}{$\begin{array}{c}\text { Age at onset of } \\
\text { thyroid gland } \\
\text { disease }\end{array}$} & \multirow{2}{*}{$\begin{array}{c}\text { Age at } \\
\text { lymphoma }\end{array}$} & \multirow{2}{*}{$\begin{array}{l}\text { Latency } \\
\text { (years) }\end{array}$} & \multirow{2}{*}{$\begin{array}{l}\text { Lymphoma } \\
\text { histology }\end{array}$} & \multirow{2}{*}{$\begin{array}{l}\text { Site of } \\
\text { lymphoma }\end{array}$} & \multirow{2}{*}{$\begin{array}{l}\text { Treatment } \\
\text { of } \\
\text { lymphoma }\end{array}$} & \multirow{2}{*}{$\begin{array}{l}\text { Thyroid status at } \\
\text { diagnosis of } \\
\text { ophthalmopathy }\end{array}$} \\
\hline & $\begin{array}{l}\text { Affected } \\
\text { sides }\end{array}$ & $\begin{array}{c}\text { Age at } \\
\text { diagnosis }\end{array}$ & Treatment & & & & & & & \\
\hline \multicolumn{11}{|c|}{ Lymphoma patients with autoimmune thyroid anomalies and prior orbitopathy } \\
\hline Male & Unilateral & 31 & $\begin{array}{l}\text { Steroids and } \\
\text { decompression }\end{array}$ & Uncertain & 50 & 19 & MZL & Retrobulbar & RT & Euthyroid $^{a}$ \\
\hline Female & Bilateral & 23 & - & 23 & 39 & 16 & MZL & Lid/Anterior & RT & Hyperthyroid \\
\hline Female & Bilateral & 29 & - & 19 & 49 & 20 & MZL & Retrobulbar & RT & Hyperthyroid \\
\hline Female & Unilateral & 42 & - & Uncertain & 53 & 11 & MZL & Retrobulbar & RT & Euthyroid $^{\mathrm{a}}$ \\
\hline Female & Bilateral & 50 & $\begin{array}{l}\text { Steroids and } \\
\text { decompression }\end{array}$ & Uncertain & 77 & 27 & DLCL & Lid/Anterior & $\begin{array}{l}\mathrm{CT} \text { and } \\
\mathrm{RT}\end{array}$ & Euthyroid $^{a}$ \\
\hline Female & Bilateral & 64 & - & 64 & 79 & 15 & MZL & $\begin{array}{l}\text { Lid/ } \\
\text { Conjunctiva }\end{array}$ & RT & Hyperthyroid \\
\hline \multicolumn{11}{|c|}{ Lymphoma patients with autoimmune thyrotoxicosis, but without orbitopathy } \\
\hline Female & (None) & NA & NA & 40 & 57 & 17 & MZL & $\begin{array}{l}\text { Lacrimal } \\
\text { gland }\end{array}$ & RT & Hyperthyroid \\
\hline Male & (None) & NA & NA & 21 & 72 & 51 & MZL & Lid/Anterior & RT & Hyperthyroid \\
\hline Female & (None) & NA & NA & 59 & 59 & 0 & MZL & $\begin{array}{l}\text { Lacrimal } \\
\text { gland }\end{array}$ & RT & Hyperthyroid \\
\hline Female & (None) & NA & NA & 68 & 68 & 0 & MZL & Lid/Anterior & RT & Hyperthyroid \\
\hline
\end{tabular}

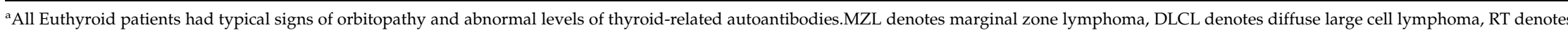
orbital radiotherapy, CT denotes chemotherapy,and NA denotes nonsignificance. 
most involve the deep orbit $(44 \%)$ or lacrimal gland $(26 \%) .{ }^{18}$ Nine of the 10 cases in this investigation were MZL, the variant commonly arising in Sjogren's syndrome, Hashimoto's thyroiditis, or H. pylori infection; the $90 \%$ proportion of MZL after autoimmune thyroid disease is, however, much greater than the $37 \%$ found in a large, unselected cohort. ${ }^{16}$ It is also of interest that $8 / 10$ lymphomas arose anteriorly, this predilection for conjunctival and lacrimal gland (as with all periocular $\mathrm{MZL}^{18}$ ) possibly reflecting the normal presence of MALT in these two tissues.

As lymphoma may emerge from a background of chronic lymphocytic stimulation - often autoimmune - the unexpectedly high prevalence (at least $1.6 \%$ ) of preceding thyroid orbitopathy in patients with periocular lymphoma (median latency 17.5 years; range 11-27) suggests a causal relationship between the two conditions. The statistical association is supported by examples of other lymphomas arising in other chronic inflammatory conditions - such as Sjogren's syndrome, Hashimoto's thyroiditis, coeliac disease, and gastric lymphoma.

\section{References}

1 Weetman AP. Graves' disease. N Engl J Med 2000; 343: 1236-1248.

2 Bahn RS, Dutton CM, Natt N, Joba W, Spitzweg C, Heufelder AE. Thyrotropin receptor expression in Graves' periocular adipose/connective tissues: potential autoantigen in Graves' ophthalmopathy. J Clin Endocrinol Metab 1998; 83: 998-1002.

3 Hyjek E, Isaacson PG. Primary B cell lymphoma of the thyroid and its relationship to Hashimoto's thyroiditis. Hum Pathol 1988; 19: 1315-1326.

4 Aozasa K. Hashimoto's thyroiditis as a risk factor of thyroid lymphoma. Acta Pathol Jpn 1990; 40: 459-468.

5 Scholefield JH, Quayle AR, Harris SC, Talbot CH. Primary lymphoma of the thyroid, the association with Hashimoto's thyroiditis. Eur J Surg 1992; 18: 89-92.
6 Mariette X. Lymphomas in patients with Sjogren's syndrome: review of the literature and physiopathologic hypothesis. Leuk Lymphoma 1999; 33: 93-99.

7 Kassan SS, Thomas TL, Moutsopoulos HM, Hoover R, Kimberley RP, Budman DR et al. Increased risk of lymphoma in sicca syndrome. Ann Intern Med 1978; 89: 888-892.

8 Swinson CM, Coles EC, Slavin G, Booth CC. Coeliac disease and malignancy. Lancet 1983; 1: 111-115.

9 Murray A, Cuevas EC, Jones DB, Wright DH. Study of the immunohistochemistry and T-cell clonality of enteropathy associated T-cell lymphoma. Am J Pathol 1995; 146: 509-519.

10 Wotherspoon AC, Ortiz-Hidalgo C, Falzon MR, Isaacson PG. Helicobacter pylori-associated gastritis and primary B-cell gastric lymphoma. Lancet 1991; 338: 1175-1176.

11 Ech M, Schmauber B, Greiner A, Muller-Hermelink HK. Helicobacter Pylori in gastric mucosa-associated lymphoid tissue type lymphoma. Recent Results Cancer Res 2000; 156: 9-18.

12 Wotherspoon AC, Doglioni C, Diss TC, Pan L, Moschini A, deBoni $\mathrm{M}$ et al. Regression of primary low grade B-cell gastric lymphoma of mucosa-associated lymphoid tissue type after eradication of Helicobacter pylori. Lancet 1993; 342: 575-577.

13 Bartley GB, Fatourechi V, Kadrmas EF, Jacobsen SJ, Ilstrup DM, Garrity JA et al. The incidence of Graves' disease in Olmsted County, Minnesota. Am J Ophthalmol 1995; 120: 511-517.

14 Tunbridge WMG, Evered DC, Hall R, Appleton D, Brewis M, Clark F et al. The spectrum of thyroid disease in a community: the Wickham Survey. Clin Endocrinol 1977; 7: 481-493.

15 Cawood C, Moriarty P, O'Shea D. Recent developments in thyroid eye disease. BMJ 2004; 329: 385-390.

16 Kendall-Taylor P, Perros P. Clinical presentation of thyroid associated orbitopathy. Thyroid 1998; 8: 427-428.

17 Jenkins C, Rose GE, Bunce C, Wright JE, Cree IA, Plowman $\mathrm{N}$ et al. Histological features of ocular adnexal lymphoma (REAL classification) and their association with patient morbidity and survival. Br J Ophthalmol 2000; 84: 907-913.

18 Jenkins C, Rose GE, Bunce C, Cree I, Norton A, Plowman $\mathrm{PN}$ et al. Clinical features associated with survival of patients with lymphoma of the ocular adnexa. Eye 2003; 17: 809-820. 